\title{
Penggunaan Aplikasi Canva Untuk Pembelajaran Ilmu Pengetahuan Sosial Kelas VI di SDN 02 Tarantang
}

\author{
Revina Junia Putri, Adam Mudinillah \\ STAI Al-Hikmah Pariangan Batusangkar, Indonesia \\ revinajuniaputri18@gmail.com, adammudinillah@staialhikmahpariangan.ac.id
}

\begin{abstract}
ABSTRAK
Khusus di SD-SMP-SMA/SMK pembelajaran ilmu pengetahuan sosial ini adalah pelajaran yang harus ada ikut masing-masing tingkatan pendidikan. Pendidikan ilmu pengetahuan sosial adalah suatu bentuk sederhana atau olahan dari pengetahuan sosial dan humanisme, dan juga suatu bentuk tindakan dasar manusia yang di wadahi dan di sampaikan secara faktual dan psikologis atau pedagogi untuk tujuan pendidikan.Untuk pelajaran IPS ini pasti sudah banyak yang megetahuinya bahwa pelajaran ini membahas tentang materi hafalan yang mana sering kali dapat mambuat siswa merasa bosan. Maka dari itu akan lebih baik dan menarik jika untuk pembelajaran ilmu pengetahuan sosial kelas vi tema sub tema 2 pembelajaran 1 di sdn 02 tarantang menngunakan aplikasi Canva. Pada masa pendemi Covid 19 ini sangat banyak mendatangkan perubahan baru didalam kehidupan manusia pada saat ini termaksud dalam dunia pendidikan. Metode penelitian yang digunakan penelitian yang di modifikasi menjadi empat tingkat sebagai berikut kajian awalan, pengenalan entitas, pembuatan produksi, dan percobaan. Belajar dengan menggunakan yang namanya tidak tatap muka atau daring adalah suatu bentuk hal baru didalam dunia pendidikan maupun bagi mahasisswa diperguruan tinggi di Indonesia, khususnya bagi mahasiswa untuk dapat menyesuaikan dengan keperluan atau kebutuhan pengajaran di kelas seperti, membuat sebuah video presentase yang menarik. Oleh karena itu, untuk memenuhi kebutuhan tersebut pendidik bisa menggunakan aplikasi canva. Penggunaan aplikasi canva untuk pembelajaran pada ilmu pengetahuan sosial mendukung untuk meningkatkan ketertarikan siswa dalam proses belajar, salah satu aplikasi yang naik daun yaitu canva yang banyak di gunakan, aplikasi tersebut berukuran kurang lebih $24 \mathrm{MB}$ dan dapat di download dengan gratis tetapi memang ada beberapa vitur di dalamnya yang tidak tersedia dengan gratis. Meskipun demikian, aplikasi tersebut tetap worth it digunakan editor media pembelajaran online.
\end{abstract}

Kata Kunci: Aplikasi Canva, IPS, Tarantang

\section{Using Canva Application for Class VI Social Science Learning at SDN 02 Tarantang}

\begin{abstract}
Especially in SD-SMP-SMA/SMK social science learning is a lesson that must be present at each level of education. Social science education is a simple or processed form of social knowledge and humanism, and also a form of basic human action that is accommodated and conveyed factually and psychologically or pedagogically for educational purposes. discussing rote material which can often make students feel bored. Therefore, it would be better and more interesting if for class vi social science learning the theme of sub-theme 2 of learning 1 in sdn 02 was tarantang using the Canva application. During the Covid-19 pandemic, there are many new changes in buman life at this time, including in the world of education. The research method used in the modification is divided into four levels as follows: preliminary study, entity introduction, production creation, and experiment. Learning by using what is not face-to-face or daring is a new thing in the world of education as well as for university students in Indonesia, especially for students to be able to adapt to the needs or teaching in the classroom, such as making an interesting
\end{abstract}


video presentation. Therefore, to meet the needs of these educators, you can use the Canva application. The use of the Canva application for learning in social sciences supports increasing student interest in the learning process, one application that is on the rise is Canva which is widely used, the application is approximately $24 \mathrm{MB}$ in size and can be downloaded for free but there are some features in it not available for free. Nevertheless, the application is still worthy of being used as an online editor's learning media.

Keywords: Canva App, IPS, Tarantang

\section{PENDAHULUAN}

Disaat ini dunia masih di kelilingi dengan diberi nama penyakit tertular atau Covid-19, yang mana bakteri ini berasal dari kota China pada bulan Desember 2019, di Indonesia itu baru mengumumkan pasien pertama nya pada tanggal 2 Maret 2020, hingga sekarang ini Indonesia lagi merasai peningkatan kuantitas sasaran jiwa akibat terkenanya penyakit ini (Fitria et al., 2021). Di era pandemi ini menuntut guru untuk melakukan beragam gebrakan-gebrakan yang baik dalam mengembangkan media pembelajaran berbasis aplikasi maupun bermacam-macam metode pembelajaran jarak jauh yang masih digunakan untuk dimasa pandemi ini (Triningsih, 2021). Perkembangan teknologi informasi dan komunikasi ini pada saat sekarang sudah sangat berkembang dan juga sudah mempengaruhi disekeliling kehidupan manusia. Di era teknologi informasi ini saat ini sudah dapat kita lihat dengan cepat dan mudahnya dalam mendapatkan informasi yang diperlukan (Purwati \& Perdanawanti, 2019). Pada masa pandemi ini sangat banyak mengalami pertukaran baru didalam kehidupan manusia termaksud didalam dunia pendidikan (Suni Astini, 2020). Dengan adanya perkembangan yang sudah terjadi itu sangat berpengaruh terhadap kegiatan yang ada pada sebuah satuan kelompok atau komunitas. Teknologi informasi dan komunikasi ini dapat kita manfaatkan dalam pembuatan sebuah perangkat pengkajian yang sangat atraktif dan sangat memukau. Bisa dilihat pada saat ini proses belajar dilaksanakan secara tidak tatap muka, pendidik harus bisa mengembangkan sebuah media pembelajaran dengan menggunakan pelajaran dari teknologi informasi komunisi ini (Hapsari \& Zulherman, 2021). Dengan kondisi pandemi seperti saat sekarang ini sejagat di pendidikan dapat memakai teknologi secara maksimal agar dapat melaksanakan proses pembelajaran yang mana tidak bisa dilakukan secara luring (Resmini' et al., 2021). Dilihat juga pada akhir dekade ini banyaknya mahasiswa yang sudah memiliki usaha sendiri, yang mana mereka ini di dukung dengan adanya kemajuan teknologi dan kemudan mendapat informasi, saat ini sudah banyaknya mahasiswa yang berhasil menjalankan usahanya dengan baik (Santi \& Mubaraq, 2020). Dapat dilihat teknologi informasi ini adalah jalan satu-satunya sebagai solusi dari pelaksanaan belajar secara online, banyak media informasi ini digunakan oeleh seorang pendidik untuk melaksanakan pembelajaran secara online (Suni Astini, 2020) 
Ada dalam proses desain pembelajaran, banyak faktor yang perlu dipertimbangkan terlebih dahulu. Di setiap faktor-faktor ini silih terikat erat antara satu dengan satu lainnya dan berpengaruh satu sama lain sampai dengan batas yang telah ditentukan. Yang mana faktor-faktor ini harus di persiapkan dengan langkah desain instruksional. Misalkan tujuan dan sasaran ini tidak terpilih atau tidak dipilih, menetap atau di tulis dengan benar, maka dari itu tindakan untuk yang akan datang bisa memuat sejumlah problem atas item yang tidak sesuai dan tidak lengkap di tindakan sebelumnya (Işman, 2011).

Untuk pembuatan desain kita dapat menggunakan aplikasi canva yang mana aplikasi canva ini adalah aplikasi online yang dapat kita gunakan untuk membuat sebuah desain grafis di berbagai keperluan seperti poster, sertifikat, dan kartu ucapan. Aplikasi canva ini juga dapat digunakan untuk mengubah foto (Purwati \& Perdanawanti, 2019). Desain merupakan yang mana suatu elemen sebagai tolak ukur kesuksesan campaign marketing. Malahan, tidak hanya itu desain ini juga tidak sedikit kita mengamati di advertensi yang unik dan menarik baik di sosial media ataupun di televisi. Tujuan dari ini biasanya sebagai brand awareness atau lebih tepat nya untuk dapat menarik perhatian pembeli. Tetapi, apabila kita hendak mempunyai design yang bagus dan memiliki kualitas tinggi tapi tidak memiliki cukup kepandaian untuk memanfaatkan photoshop atau corel draw lalu canva ini adalah jalan keluar yang terbaik. Canva ini dapat menunjang kita untuk memanifestasikan desain tanpa ada perlu menginstal aplikasinya terlebih dahulu. Didalam tools nya canva ini kita juga dapat menemukan dengan mudah animasi dan desain yang bisa dengan mudah kita edit didalamnya tanpa ada perlu mendesainnya dari pertama. Aplikasi canva ini sangatlah pas bagi kitakita yang pemuka karena dengan fitur drop dan drag nya dapat menunjang kita melaksanakan desain apapun itu dengan super cepat.

Aplikasi canva ini merupakan sebuah tools yang berguna untuk membuat desain ilustratif agar dapat mempertemukan pemakai supaya kita dapat dengan gampang mempersiapkan beragam bentuk desain artistik. Dimulai dengan membuat kartu ucapan, surat tempelan, edaran, sampai ke peragaan juga. Canva saat ini tentu tersaji didalam beberapa bentuk, situs-situs lainnya. Sejarah dari Canva ini berawal dari tahun 2012, lebih tepat pada tanggal 1 Januari yang menjadi hari awal muncul dari aplikasi canva ini. Pendiri dari aplikasi canva ini yaitu Melanie Perkins yang mana aplikasi canva ini didirikan oleh Fusion Books, penerbit buku ternama yang berasal dari Australia. Pada tahun pertama peluncuran aplikasi canva ini, Canva meningkat dengan mencetak rekor yang menggunakan sebesar 750.000 (Pratiwi et al., 2020). Lima tahun berlangsung, pada tahun 2017 Canva ini mulai memperoleh tingkat di mana perusahaan sudah mulai mencatat labanya. Pada saat itu mereka sudah memakai 200 orang pekerja yang tertebar di kantor Australia dan San Fransisco. Dengan berjumlah sebanyak 294.000 pengguna itu merupakan salah satu pemasukan yang sangat 
besar atau terbesar datang dari pengguna premium. Per 2017, dengan cakupan layanan yang sampai 169 negara ini aplikasi canva ini mempunyai 10 juta pengguna.

\section{Cara Menggunakan Aplikasi Canva}

\section{Sign-Up ke Canva}

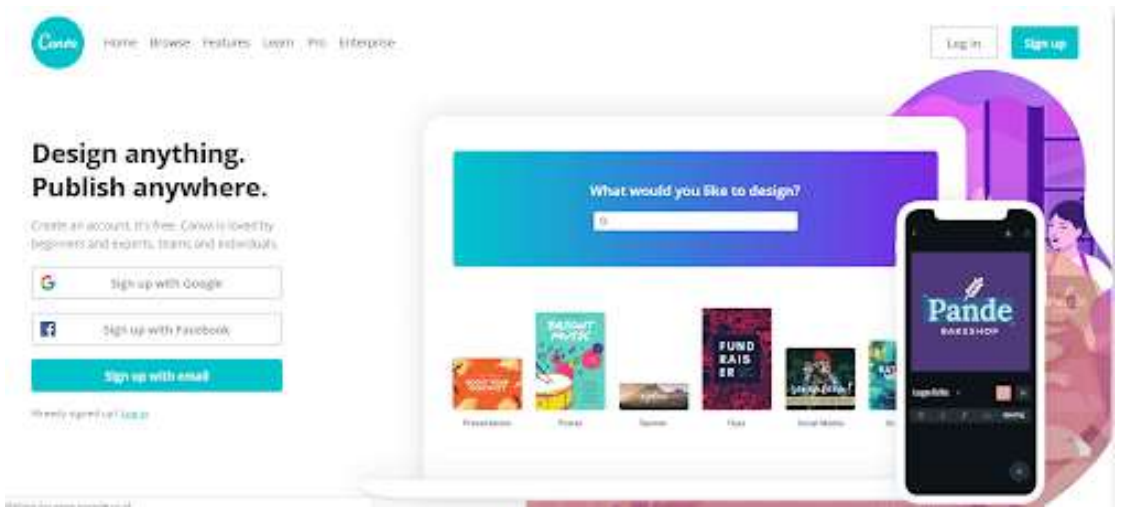

Gambar 1. Tampilan Awal Canva

Untuk awal, kita perlu mempunyai akun Canva, kita bisa masuk di https://www.canva.com. Ada tampak sebagian pilihan untuk Gmail, Fb ataupun pendaftaran dengan mengisi data pribadi kita untuk memiliki akun canva.

\section{Pilih Kebutuhan Anda}

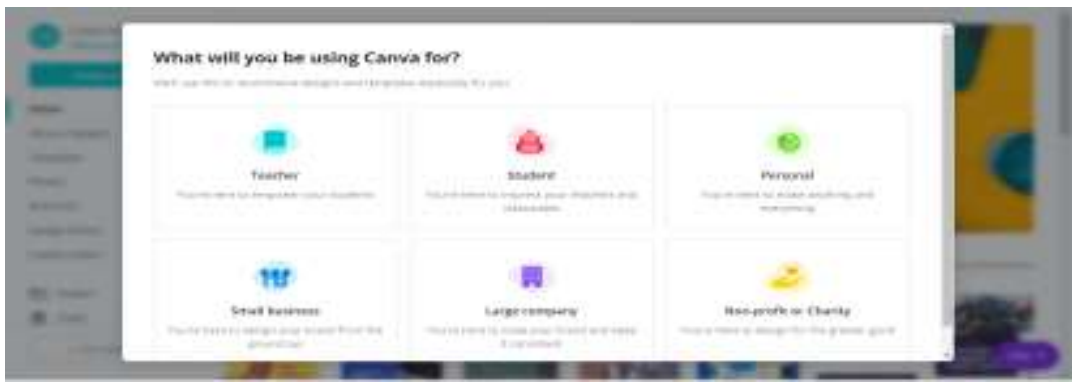

Gambar 2. Tampilan Kedua Canva (Opsi atau Pillihan)

Selanjutnya, kita sudah disediakan beberapa saringan agar dapat menunjuk apa saja yang akan kita lakukan dengan akun Canva kita sendiri. Pilihlah sesuai keperluan kita. contohnya, kita sedang memerlukan canva untuk membuat desain bisnis online produk kita. Kita dapat memakai satu sisi atau small business.

\section{Demo dan Jenis Desain}




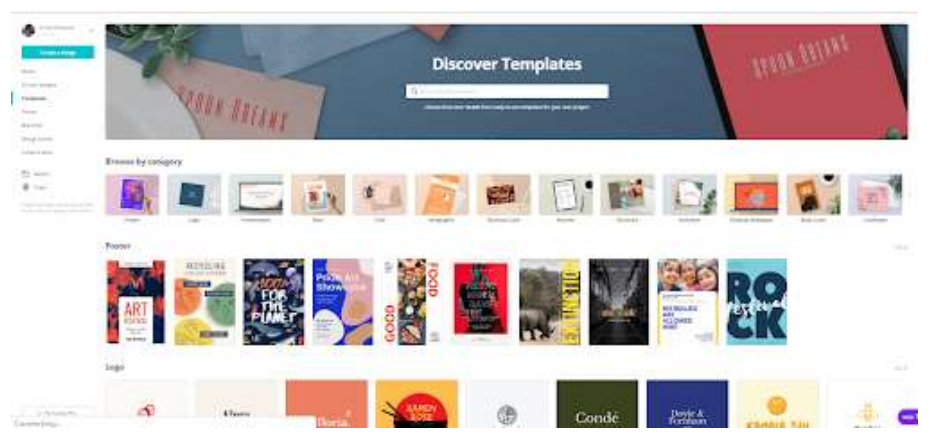

Gambar 3. Jenis Desain

Setelah itu, kita bisa mengundi layout graphic. Yang mana sudah dijelaskan pada awalnya, kita bisa mewujudkan beraneka ragam graphic di Canva. Di aplikasi ini menyajikan beraneka ragam layout dengan format yang telah ada untuk platformnya.

\section{Pilih Gambar Yang Akan Digunakan}

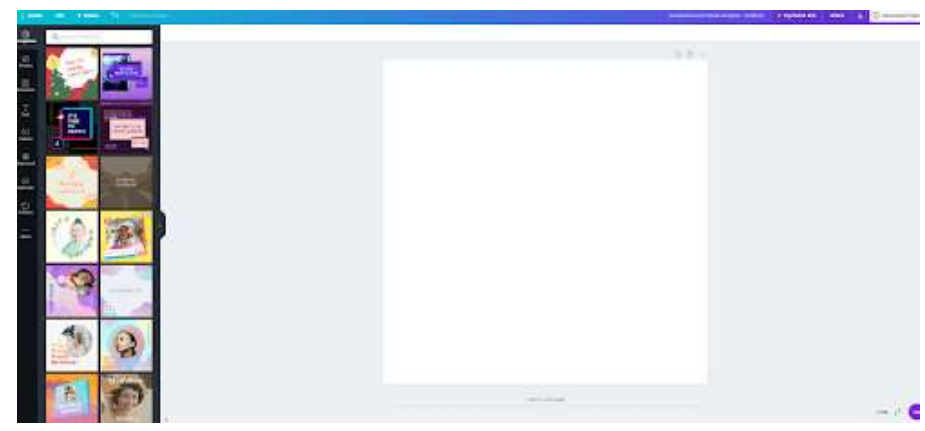

Gambar 4. Backround Pilihan

Sudah ada diaplikasi ini dijelaskan ada jumpa lembar kerja kita ialah segiempat yang bercorak putih yang mana adalah tempat desain yang akan kita buat nanti. Dengan banyak template, kita tidak perlu mulai dari awal. kita juga bisa memasukkan picture diri kita.

\section{Desain Sesuai Keinginan}

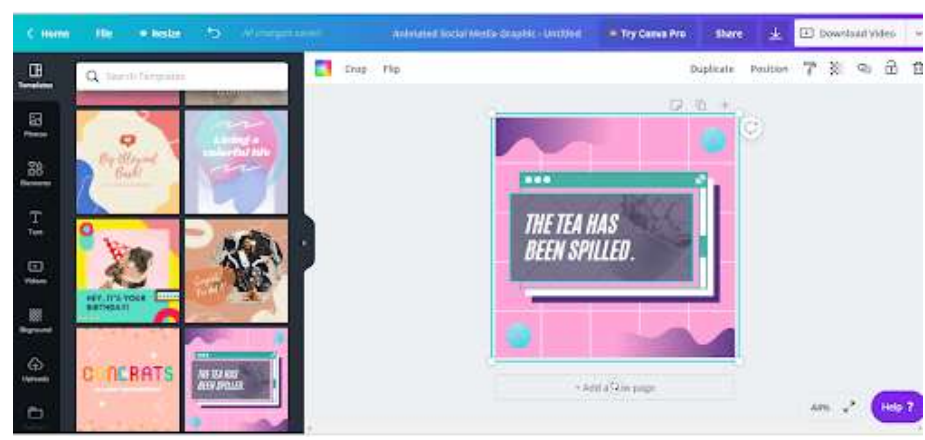

Gambar 5. Memilih Desain

Contohnya, kita dapat memakai dari berbagai bentuk template yang bisa di drop dan drag di tempat kita bekerja.

Pembelajaran ilmu pengetahuan sosial ini merupakan pembelajaran yang wajib ada ikut masing-masing tingkatan sebuah pendidikan. Pendidikan ilmu pengetahuan sosial adalah suatu 
bentuk sederhana atau olahan dari pengetahuan sosial dan humanisme, dan juga suatu bentuk tindakan dasar manusia yang di wadahi dan disampaikan secara faktual dan psikologis atau pedagogi untuk tujuan pendidikan.

Dijelaskan didalam UUD RI nomor 11 tahun 1992 mengutarakan hingga pada hakikatnya penyusunan teritorial di Indonesia ini merupakan mewujudkan manusia Indonesia yang utuh. Jadi kegiatan ini menyatakan bahwa pembangunan di Indonesia ini tidak hanya memiliki berupa dari alat-alat saja. Tetapi, ada pula terletak pada tingkat jenis di sumber daya manusianya juga. Ada dari beberapa cara untuk menaikkan kualitas dari sumber daya manusia ini yang mana dapat melaui pendidikan (Nasrullah et al., 2018). Pembangunan nasional adalah proses yang mana berlangsung secara dinamis, itu bertuan untuk mewujudkan sumber daya manusia yang sangat berkarakter dan mempunyai daya saing. Tujuan adanya pembangunan nasional ini agar dapat mewujudkan seluruh elemen-elemen pembangunan agar dapat berkontribusi termasuk elemen pendidikan, yang mana itu baik pendidikan formal ataupun pendidikan non formal (Farmawati et al., 2018). Dan apabila seseorang guru itu sudah berkualitas baik, maka sudah pasti pendidikan nya itu juga bagus, jika yang dilakukan oleh guru hari demi hari itu tambah baik, maka keadaan dunia pendidikan ini akan menjadi lebih baik, terkhusus dalam menambah generasi yang berpendidikan atau terdidik (Farmawati et al., 2018).

Pendidikan sekolah ini merupakan suatu lembaga pembinaan dari sumber daya manusia Indonesia yang ada tahap nya atau berkelanjutan, seperti pengembangan kemampuan siswa aspek kognitif, afektif maupun psikomotor (Imron, 2021). Pendidikan di Indonesia juga sebagai bentuk hal yang penting dari kehidupan masyarakat yang tidak dapat dijauhkan atau dibuang dari pertambahan dan pergantian yang ada terjadi di lingkungan sekitar kita sendiri, dengan adanya pergantian yang terjadi di dunia struktur kerja yang disebabkan cepatnya kemajuan ilmu pengetahuan dan teknologi serta diberlakukannya era global ini mewajibakan agar lembaga pendidikan dapat betul-betul mendapatkan jebolan yang sangat berkarakter dan memiliki daya saing yang kuat (Tiawan et al., 2020).

Tujuan dari pelaksanaan Pendidikan adalah agar dapat mewujudkan angkatan yang berkualitas, sebagaimana ini tanggapan atas kejadian kebejatan moral bagi turunan muda pada saat ini (Nurhisam, 2017). Perwujudan dari pendidikan yang berkarakter harus pandai dengan internalisasikan sikap budi pekerti yang cocok dengan aktivitas harian kita, didalam berbagai bentuk jenisnya (Bahri, 2015). Untuk dapat mewujudkan generasi yang berkualitas, karakter penting lah dapat diintegrasikan di dalam proses pembelajaran. Pengembangan sumber daya manusia itu dapat dimulai dengan adanya pendidikan dasar, pendidikan menegah dan juga setelah itu sampai ke perguaruan tinggi, itulah yang mana salah satu modal yang sangat bernilai bagi 
pemajuan warga kita juga (Yulianti, 2019). Adanya perombakan kualitas dari pendidikan secara terus menerus dilaksanakan oleh pemerintah ataupun penyelenggara pendidikan, hal itu dapat dibutuhkannya upaya agar dapat menaikkan mutu pendidikan ini, terutama dari guru sendiri, karena apa guru ini sebagai pendidik di paling depan yang mana tugas dan fungsi dari seorang guru ini berkomunikasi secara langsung dengan siswa, ada juga tugas paling utama dari seorang guru dalam pembelajaran di sekolah yaitu untuk membangun suasana dalam belajar yang tidak membuat siswa bosan sehingga adanya dampak positif di dalam pencapaian dari prestasi belajar siswa ini (Abdul Syukur, 2014).

Di aktivitas yang bakal dilalui oleh peserta didik di era yang akan tiba dengan sebuah pendidikan lah siswa ini dapat menjadi solusi yang baik dalam berbagai problema yang terjadi. Maka dari itulah, peran dari sebuah pendidikan ini adalah bagaimana melahirkan angkatan yang mempunyai cara berfikir, cara bersikap, dan cara melakukan sesuatu yang cocok dengan asli dari diri umat bangsa (Rahmatullah et al., 2020). Maka dari itu, kehidupan yang cerdas, dan aman dapat dilaksanakan melalui pendidikan (Rosmawati, 2018).

Saat ini sudah banyaknya penggunaan media sosial yang mana dengan maraknya penggunaan media sosial ini dapat membuka lahan atau peluang bagi para usaha dalam memasarkan sebuah produknya (Sholeh et al., 2020). Bagian yang sangat penting dalam proses desain pembelajaran itu adalah media. Dengan adanya media ini lah, apapun pesan dari pendidik kepada peserta didik tersampaikan dengan baik dan lancar. Di dalam pengkajian inilah, media pembelajaran yang dibentuk yang mana merupakan audio visual yang ditata memakai aplikasi canva. Di dalam pembelajaran ilmu pengetahuan sosial guru sangat membutuhkan keaktifan yang baik dari siswa itu sendiri tidak hanya siswa saja guru pun harus dapat menjelaskan dengan keaktifan yang baik. Peran dari guru yang inovatif itu sangat dibutuhkan sebagai pengajar atau pedoman bagi siswa agar dapat membantu siswa untuk memupuk potensi agar siswa bisa mendapatkan pengalaman baru dan juga pengetahuan selam proses belajar mengajar yang diberi oleh guru (Ramli etal., 2018).

Di dalam prosedur pembelajaran modern pada sekarang, peserta didik itu tidak hanya berperan menjadi pendengar atau pemeroleh saja, tetapi peserta didik ini juga harus berbuat atau beraksi sebagai komunikator atau penyampai pesan (Nurseto, 2012). Pembelajaran adalah satu bentuk kegiatan yang terjadi dari elemen-elemen yang sangat berjiwa kemanusiaan, yang mana layanan atau prasarana, dan metode proses yang saling berkaitan dan dapat merajai satu sama lain itu guna untuk mencapai agar tujuan dari pembelajaran itu sendiri (Bakri et al., 2021). Salah satu pembelajaran yang ada disekolah dasar itu adalah mata pelajaran IPS, yang mana IPS ini merupakan paduan dari sejumlah mata pelajaran contoh, ada ekonomi, sosiologi, sejarah, 
antropologi dan geografi (Yuanta, 2020). Dengan adanya salah satu patokan adalah bagaimana pendidikan dilaksanakan secara global dan terus-menerus pada sudut pandang di aktivitas didalam kehidupannya (Rahmatullah et al., 2020). Untuk ada peningkatan yang berkualitas tentunya dari sebuah pembelajaran tersebut banyak pembelajaran itu sendiri dirancang dan dilaksanakan oleh guru (Mahardika et al., 2021). Kesuksesan dari prosedur pembelajaran yang mana ada beberapa diakibatkan oleh kecermatan segi guru (Rahmatullah et al., 2019). Maka dari itu diperlukan kepandaian IPTEK, rencana di pembelajaran ini untuk diaplikasikan didalam ruangan (Ramli et al., 2018). Maka dari itu, pembelajaran bermutu dan berkarakter dimulai dari pendidiknya dulu yang bermutu. Seandainya guru bertambah baik dari hari kehari, maka Pendidikan juga akan bertambah baik dan berkualitas (Farmawati et al., 2018). Terdidik dalam arti guru harus memiliki sikap yang bertanggung jawab melaksanakan sistem pembelajaran. Di dalam melaksanakan pembelajaran salah satu metode mengajar yang baik, secara efektif, serta mengikuti perkembangan teknologi pada saat sekarang ini ialah dengan dilaksanakan pembelajaran dengan media pembelajaran yang mana media ini sebagai rujukan utama dari berlangsungnya belajar mengajar (Garris Pelangi, 2020). Penerapan meruapakan suatu langkah yang benar adanya untuk melaksanakan bentuk pembelajaran yang sedang dirancang, artinya dilantai ini semua yang sudah kita kembangkan di atur sedemikian rupa sesuai dengan fungsi dan perannya agar bisa diterapkan (Wicaksana et al., 2020). Di dalam kegiatan pembelajaran ini telah drancang oleh guru dengan sebegitu tersusun agar siswa dapat menangkap dan menguasai materi yang disampaikan oleh guru kepada siswa, sebelum itu guru harus mempersiapkan rencana-rencana nya terlebih dahuluh agar dapat mempermudah falam mencapai tujuan pendidikan, yang mana salah yang harus dipersiapkan oleh guru yaitu media pembelajaran (Tahun et al., 2021).

Teknologi yang digunakan untuk kebutuhan pembelajaran yang juga tahu dengan sebutan yang namanya media (Mahnun, 2012). Apabila media yang digunakan itu dibuat secara optimal maka manfaat dari media itu akan dirasakan. Kelebihan dari sebuah Media Audio visual yaitu pesan tulisan maupun lisan itu dapat ditampilkan dengan baik, jelas, waktu dan daya indera, dapat mengatasi keterbatasan ruang, dapat digunakan. Badan Ekonomi Kreatif (Bekraf) telah menyampaikan bahwa desain dari komunikasi visual ini adalah salah satu kawasan yang sangat maju dengan pesat (Rahmasari \& Yogananti, 2021). Ada salah satu aplikasi yang dapat membuat sebuah desain pembelajaran atau membuat konten audio visual secara alternatif yaitu canva. Dengan menggunakan aplikasi canva kita dapat membuat desain media pembelajaran dan aplikasi canva ini bersifat gratis dan berbayar. Untuk situsnya, kita dapat membuka di www.canva.com. Melalui canva ini, kita juga dapat menemukan template yang bisa kita gunakan untuk grafik, infografis, logo. Brosur, flayer, presentasi, kartu, surat kabar, kepala surat, dokumen, video, lembar 
kerja dan lain-lain. Adapaun cara untuk menggunakan aplikasi canva ini yaitu; membuat desain, memilih backround, menambah teks, membuat desain, mengedit backround, membagikan atau mengunduh desain.

Pada abad ke-18 ilmu sosial adalah sebagai bidang studi akademis yang mana pada saat itu berkembang dari Age Of Enlightenment (Age Of Reason) di Eropa. Pada saat itu ada para intelektual besar yang meletakkan dasar untuk studi ilmu sosial ini di Dunia Barat yaitu Adam Smith, Denis Diderot, Immanuel Kant, David Hume, Voltaire, dan Jean-Jacques Rousseau. Salah satu ilmu yang dapat kita pelajari yaitu ada ilmu sosial, tetapi banyak juga ilmu selain dari ilmu sosial ini yang mana dapat kita pelajari sesuai dengan apa keinginan seseorang atau minat masingmasing. Pengertian dari ilmu sosial itu adalah ilmu yang berhubungan atau berkaitan dengan manusia, lingkungan, atau bisa dengan interaksi manusia dengan manusia lainnya, kelompok dengan kelompok lainnya.

Untuk dapat menjalin komunikasi manusia ini dapat berinteraksi manusia dengan manusia lainnya agar bisa silih menekuni satu dengan yang lainnya (Pebriana, 2017). Melainkan itu, manusia itu juga bisa saling tolong menolong antar sesama berkat adanya ikatan komunikasi tersebut sehingga dapat terjalin suatu hubungan yang rukun dan serempak. Namun, kadang-kadang juga muncul sebuah konflik itu akibat dari ketidakrukunan atau adanya ketidaksesuaian hubungan dengan yang lainnya. Apabila konflik ini tidak dapat diselesaikan maka dari itu suatu hubungan ini dapat mengganggu keharmonisan di dalam lingkungan. Dengan konvesional dalam menyelesaikannya, maka dari itulah pribadi dapat hidup berdampingan dengan pribadi yang lainnya meskipun masalah yang terjadi sungguh-sungguh ada kalanya tidak dapat kita jauhkan. Ilmu sosial jika kita bisa pahami lebih sungguh-sungguh lagi didalamnya ada telaah tentang masalah dari sosial yang mana sudah sering terjadi didalam kehidupan sehari-hari masyarakat bangsa Indonesia. Berikut ini jenis-jenis dari ilmu sosial.

1. Antropologi

Antropologi ini adalah dari ilmu sosial. Ilmu ini merupakan suatu ilmu yang membahas tentang manusia dan kultur. Dalam bentuk umum, antropologi ini membahas tentang manusia yang mana ada lima sub yakni ada kemajuan manusia secara ilmu hayat, perekmbangan dan penyebaran budaya manusia, keanekaragaman dari jati diri manusia, kemajuan dan penjangkitan bahasa, validitas manusia, dan budaya yang sudah ada diseluruh dunia. Jika tidak ada ilmu sosial ini maka masyarakat tidak akan bisa mengetahui dari beragam kultur yang ada didunia. Dengan belajar antropologi ini adalah termuat dari pemeliharaan kultur, karena sama-sama kita ketahui bahwa adat apa saja yang ada dan perlu untuk disebar luaskan didalam hidup manusia pada saat ini. 
2. Sosiologi

Sosiologi merupakan ilmu yang membahas tentang beraneka ragam fenomena kehidupan penduduk atau masyarakat. Awal mulanya sosiologi ini berkembang di Eropa, dikarenakan ilmuwan sendiri lah mengenali harus ada ilmu yang dapat membahas dari transfigurasi sosial yang mana terjadi di dalam hidup masyarakat. Ada seorang ilmuwan yang terutama kali mencetuskakn sosiologi ini yaitu seorang ilmuwan yang berasal dari Prancis yang bernama August Conte. Oleh para sosiologi, August Comte disebut sebagai Bapak Sosiologi. Sosiologi ini merupakan suatu jenis ilmu sosial dikarenakan ilmu ini tidak membahas ilmu pasti, maka dari itu sebab belajarnya pelajaran ini adalah gejala dari masyarakat dan pergantian-pergantian sosial yang ada terjadi didalam kehidupan.

3. Ilmu Komunikasi

Untuk interaksi antar perorangan antara satu dengan satu yang lainnya itu tidak terlepas dari yang namaya komunikasi. Manusia juga membutuhkan yang namanya komunikasi agar dapat menyampaikan pesan dengan baik dan maksud tujuan dari pesan itu juga tersampaikan dengan baik sesuai tujuan nya. Seorang ilmuwan udah lama membahas tentang macam mana komunikasi dengan baik itu sampai dengan baik juga antar perorangan. Pengkajian yang dilaksanakan oleh tepian ilmu tersebut muncullah ilmu komunikasi. Maksud dari ilmu komunikasi yaitu ilmu yang membahas prosedur interaksi individu, baik itu antara perorangan dengan perorangan, perorangan dengan tim, maupun tim dengan tim.

4. Ekonomi

Dapat kita lihat bahwa dikehidupan sosial manusia itu tidak dapat jauh dari yang namanya ekonomi. Kenapa ekonomi itu termasuk kedalam jenis dari ilmu sosial?nah kegiatan ini karena bahwa didalam dunia ekonomi itu, yang namanya kelakuan manusia ialah termasuk bahan pembahasan utamanya. Ilmu ekonomi ini membahas macam mana dengan kelakuan manusia dalam memakai sumber daya ekonomi yang ada untuk mencukupi keperluan didalam kehidupannya sehri-hari.

5. Ilmu Pendidikan

Interaksi yang ada terjadi di anatara guru dan siswa itu merupakan hal yang sangat perlu dan harus kita pelajari didalam dunia pendidikan. Ilmu sosial itu sangat penting untuk kita miliki terutama yang terlibat atau bekerja didalam dunia pendidikan. Sebagai seorang pendidik itu harus dapat mengetahui bagaimana saja karakter dan watak dari siswa nya hingga ia dapat melaksanakan teknik pembelajaran yang cocok agar dapat membagikan 
ilmu yang ia miliki. Keterampilan berkomunikasi itu sangat dibutuhkan didalam dunia pendidikan.

6. Geografi

Di dalam geografi itu merupakan suatu ilmu yang membahas atau mempelajari tentang bumi dan isinya. Didalam geografi ini juga membahas beragam bentuk alam yang ada dijumpai di sekitar kita. Kalau dilihat sepintas geografi ini tidak ada korelasi dengan ilmu sosial, tetapi jangan salah-salah. Geografi ini sangat mempunyai ikatan yang kuat dengan ilmu sosial. Dalam geografi, manusia dengan lingkungan sekitar merupakan pusat kajiannya.

7. Sejarah

Adanya perubahan dari kejadian pada manusia sejak awal kali ada sampai saat ini terus dipelajari. Ilmu yang membahas tentang kejadian tersebut disebut dengan ilmu sejarah. Secara kronologisnya, dengan adanya ilmu historia ini menguji untuk merangkum dari berbagai kejadian yang pernah terjadi pada masa lampau hingga dapat menajdi seperti saat sekarang ini. Ilmu sejarah ini juga membahas tentang kronologi bagaimanakah proses dari terjadinya sikap seorang manusia secara berurutan berdasarkan kenyataan yang telah ada hingga historia ini tidak dapat dinamakan ilmu yang berkelakuan khayalan.

8. Ilmu Politik

Ilmu yang tiada bisa dijauhkan dari ilmu sosial yaitu adalah ilmu politik. Bagaimana dari jalannya kekuasaan didalam kehidupan masyarakat dalam negara itu adalah fokus utama yang sangat penting didalam studi ilmu politik ini . Otoritas yang dijalankan bisa bersifat antara warga negara yang satu dengan satu yang lainnya, warga dengan negaranya, maupun negara dengan negara lainnya. Kajian yang lebih pertamanya itu ialah bagaimana dengan negara untuk dapat memperoleh, menegakkan, dan memakai jabatannya sesuai dengan norma-norma yang sudah ada di negara kita ini. Secara tidak langsung, ilmu sosial juga sangat berperan. Jika tidak ada ilmu sosial, maka ilmu politik ini pasti sulit untuk menampung dari keperluan masyarakat umum.

9. Hukum

Didalam antarbangsa undang-undang, kehidupan sosial masyarakat tidak bisa kita pisahkan untuk dapat kita pelajari. Bagi yang menjejaki pendidikan di dalam bidang hukum, proses sosial ialah salah satu pokok pembahasan yang kita pelajari. Manusia merupakan makhluk sosial dan setiap tindakan dan perbuatan manusia itu harus dipimpin dan ditujukan.

10. Psikologi Sosial 
Ada suatu hal yang sangat tidak bisa dipisahkan antara satu sama lainnya yaitu psikologi sosial. Psikologi berusaha menguraikan dari sistem perwujudan dari intelentual atau psikis manusia yang memunculkan tingkah laku. Manusia itu ialah suatu bentuk kajian yang sangat diutamakan dari dalam kolaborator. Sebagai makhluk sosial, manusia ini sangat banyak mempunyai tindakan atau budi pekerti yang berbeda antara perilaku satu dengan perilaku yang lainnya.

\section{METODE PENELITIAN}

Pengkajian ini yakni pengkajian yang di modifikasi menjadi empat tingkat yang mana antara lain kajian awalan, pengenalan entitas, pembuatan produksi, dan percobaan. Percobaan dilaksanakan pada siswa di SDN 02 Tarantang. Data yang di peroleh dari hasil pengembangan dan percobaan desain meliputi data kualitatif. Percobaan ini memakai ancangan atau pendekatan PTK dengan model spiral yang mana akan di tunjukkan dakam gambar 1 berikut:

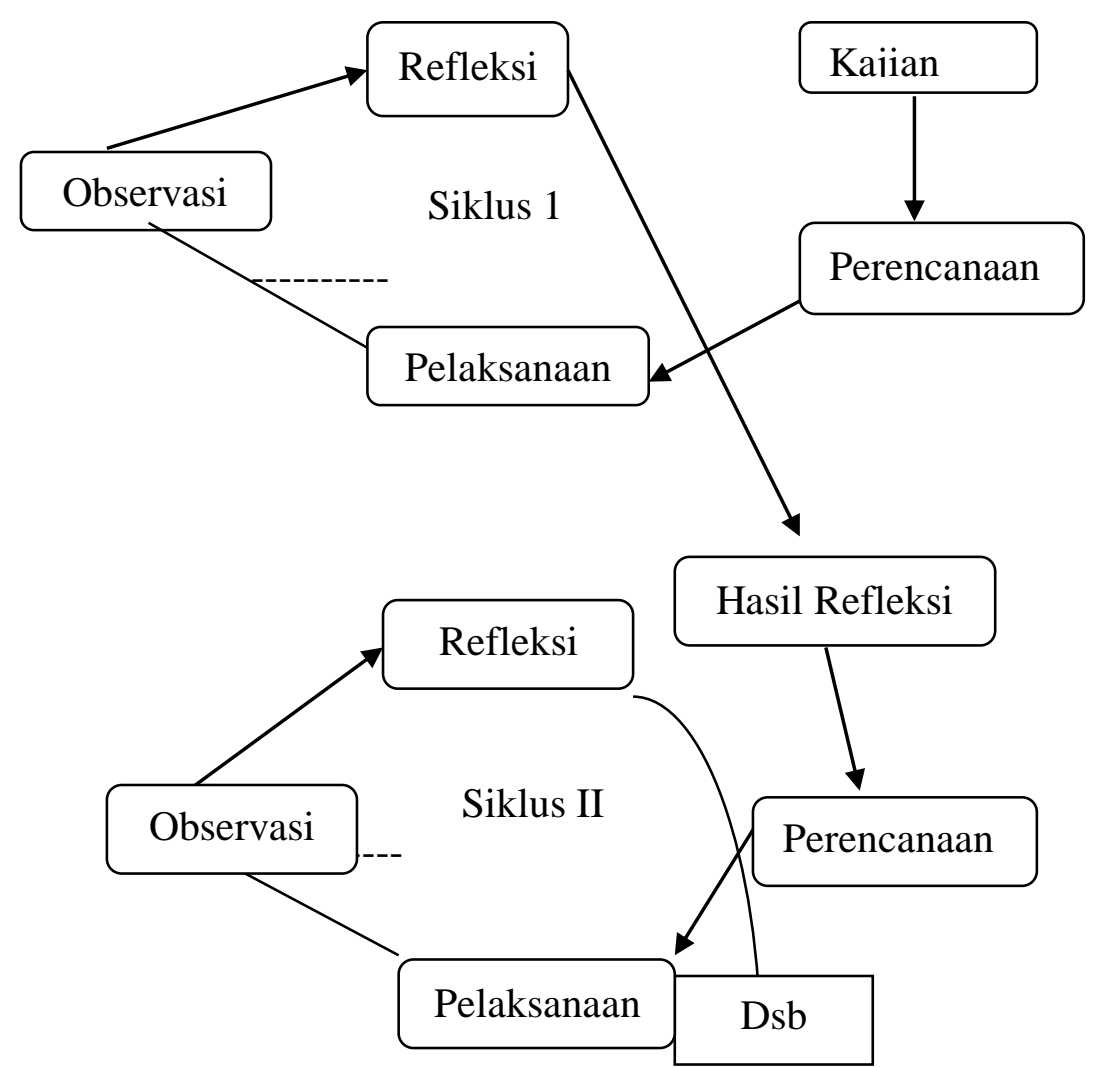

Keterangan:

Gambar 6. Desain PTK yang digunakan

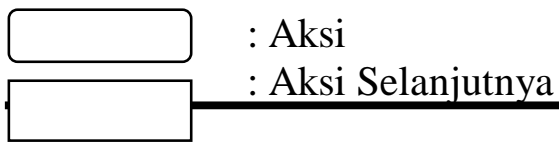




\section{$\stackrel{-}{\longrightarrow}:$ Proses Bersamaan}

Di dalam penafsiran dapat digunakan perbandingan kategori. Keadaan ini yang akan dapat menjadi penunjuk benar kah prosedur pembelajaran yang telah berlansung itu bisa di kategorikan berhasil atau tidak berhasilnya, Kategori tersebut akan di sajikan pada tabel berikut:

Tabel 1. Intrepretasi Kelayakan

\begin{tabular}{lll}
\hline Capaian & Kategori & Ket \\
\hline $\mathbf{8 4 , 1 \% - 1 0 0 \%}$ & Sangat Baik & Berhasil \\
$\mathbf{7 4 , 1 \% - 8 4 \%}$ & Baik & Berhasil \\
$\mathbf{6 4 , 1 \% - 7 4 \%}$ & Cukup Baik & Berhasil \\
$\mathbf{5 4 , 1 \% - 6 4 \%}$ & Kurang Baik & Tidak Berhasil \\
$<.54 \%$ & Sangat Tidak Baik & Tidak Berhasil \\
\hline
\end{tabular}

\section{HASIL DAN PEMBAHASAN}

\section{Hasil Dari Kajian Awal}

Untuk pembahasan yang utama didalam pembentukan aturan pembelajaran ilmu pengetahuan berbasis audio visual dengan penggunaan canva. Informasi yang di peroleh secara menyeluruh bahwa siswa sangat setuju memakai media pembelajaran ilmu pengetahuan sosial berbasis Audio Visual dengna aplikasi canva. Maka dari itu perlu adanya dilaksanakan karena dapat terlihat menarik dalam penyampaian materi pelajaran, serta meningkatkan ambisi siswa siswa ubtuk belajar, apalagi pembelajara dilakaukan secaraa tidak tatap muka. inilah memjadi salah satu alasan kenapa penggunaan aplikasi canva untuk pembelajaran ilmu pengetahuan sosial kelas vi tema sub tema 2 pembelajaran di sdn 02 tarantang, selain itu alasan lainya bahwa belajar disituasi dimasa pandemi covid 19 benar-benar harusdilakukan secara tidak tatap muka dengan memakai aplikasi yang gampang di akses baik oleh peserta didik ataupun oleh pendidik.

\section{Kelayakan Desain Media Pembelajaran}

Awal mula di gunakan, seharusnya media Audio Visual berbasis aplikasi canva ini lebih harus di validasi terlebih dahulu. Hasil penilaiaan ahli sebagai berikut:

\section{Tabel 2. Hassil Penilaian Terbatas Siswa}




\begin{tabular}{|c|c|c|c|c|c|}
\hline Aspek & $\begin{array}{l}\text { Skor } \\
12345\end{array}$ & $\begin{array}{l}\Sigma \\
\text { Bobot }\end{array}$ & $\begin{array}{l}\Sigma \\
\text { Butir }\end{array}$ & $\begin{array}{l}\Sigma \\
\operatorname{Max}\end{array}$ & Persen \\
\hline $\begin{array}{l}\text { Kelengkapan } \\
\text { Konten }\end{array}$ & 05126697 & 795 & 9 & 900 & $(\%)$ \\
\hline $\begin{array}{l}\text { Kemenarikan } \\
\text { Tampikan }\end{array}$ & 0 2154657 & 518 & 6 & 600 & 88,33 \\
\hline Desain & & & & & 86,33 \\
\hline Jumlah & & 1.313 & 15 & 1.500 & 87,53 \\
\hline
\end{tabular}

Sumber: Hasil olah data, 2020

Persentase skor hasil uji coba dilihat dari aspek media yaitu:

$\mathrm{P}=\underline{\text { Skor perolehan X } 100 \%}$

Skor maksimal

$P=\underline{1313 x} 100 \%$

1.500

$=87,5$

Berlandaskan hasil dari jawaban siswa pada table 5.3, bahwa bisa disimpulkan untuk aplika canva ini layak kita gunakan dengan presentase skor 86,73 persen untuk membuat media pembelajaran berbasis audio visual. Hasil ini digolongkan sangat cocok. maksudnya desain media pembelajaran tersebut disenangi oleh peserta didik dari bagian keutuhan konten begitupun dari tampilannya, maka dari itu dapat dipakai di sekolah tempat uji coba aplikasi canva ini. Uji coba lapangan dilaksanakan pada salah satu sekolah dasar 02 Tarantang. Didalam pengkajian ini tempat uji coba dilakukan pada siswa kelas VI Tema V sub tema II. Dalam percobaan ini diaplikasikan model penelitian tindakan kelas. Langkah-Langkah didalam proses ancangan ini sebagai berikut.

Pertama, masuk ke akun canva. Tingkat pertamnaya dalam memakai aplikasiini ialah kunjungi situs www.canva.com setelah itu masuk memakai akun yang telah didaftarkan. Selain dari itu, kita dapat juga masuk dengan akun media sosial lainnya. Kemudian, merancang media pembelajaran pada Canva sudah dapat dikerjakan. Untuk tampilan halaman pertama/log ini sebagaimana gambar 2 berikut. 


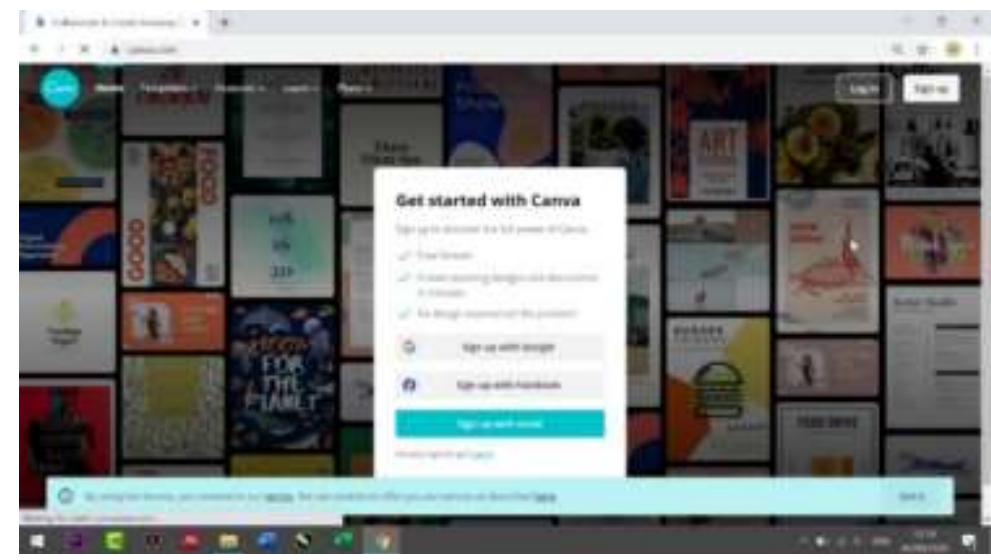

Gambar 7. Tampilan Pertama Canva Sumber: www.canva.com , 2020.

Kedua, dapat menunjuk template untuk mulai pertama desain. Kalau sudah berhasil masuk, setelah itu akan keluar tampilan halaman yang pertama. Kita dapat merancang dengan menunjuk menu create a design/membuat desain sebagimana tanda pada gambar berikut. Kemudian, pilihlah beberapa template presentasi visual yang akan dipakai. Tampilan halaman ini

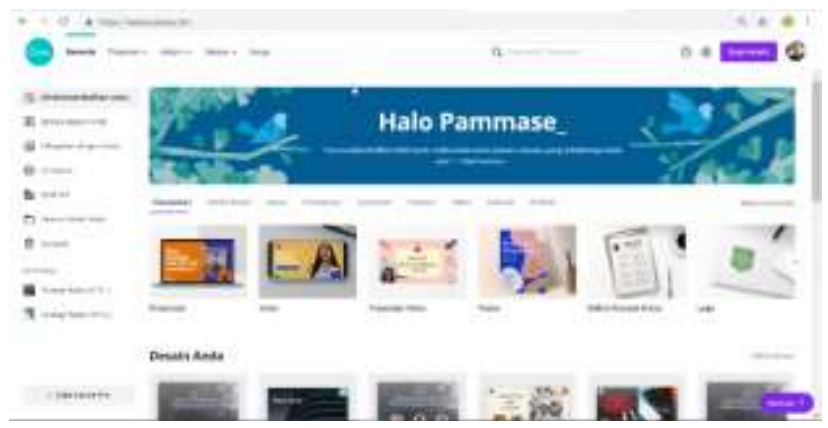

Gambar 8. Tampilan pilihan Template pada canva

Sumber: www.canva.com , 2020

Dikajian ini, yang akan dipelajari ialah desain pembelajaran berbasis audio visual, maka yang dipilih adalah template presentasi. Disini ada disajikan banyak template presentasi yang sudah dipersiapkan didalam canva tapi untuk kepentingan pengkajian ini jadi kita pilih salah satu dari background dalam template teknologi. Untuk memilih background ini merupakan proses awal didalam bagian ini. Menu yang dapat dipilih ada dua yaitu Photos dan latar. Hal ini seperti yang tertera sebagai berikut: 


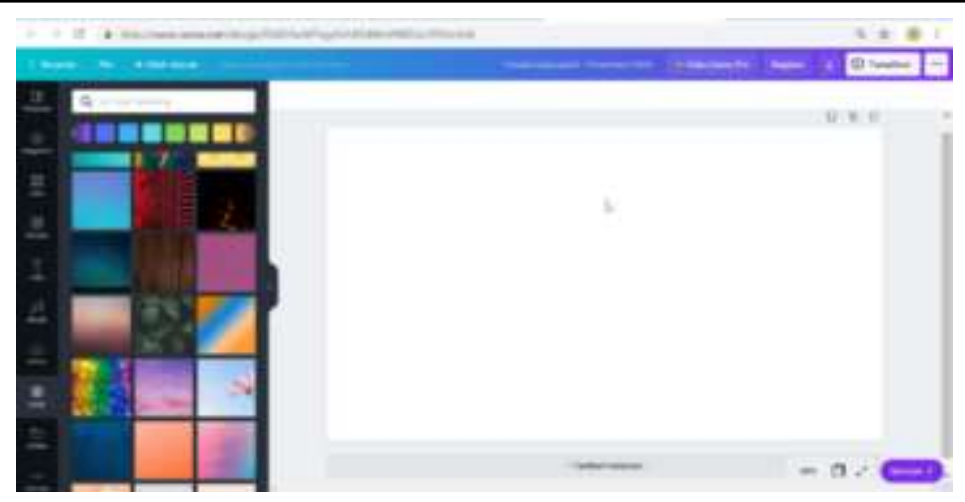

Gambar 9. Tampilan pilihan Foto dan latar

Template

Sumber: www.canva.com , 2020

Ketiga, memasukkan teks dipakai dua cara. Cara pertama tetap memakai teks yang disediakan dalam template canva. cara kedua dengan menunjuk secara buku petunjuk atau manual pada menu teks. Hal ini dapat dilihat pada gambar 6 berikut:

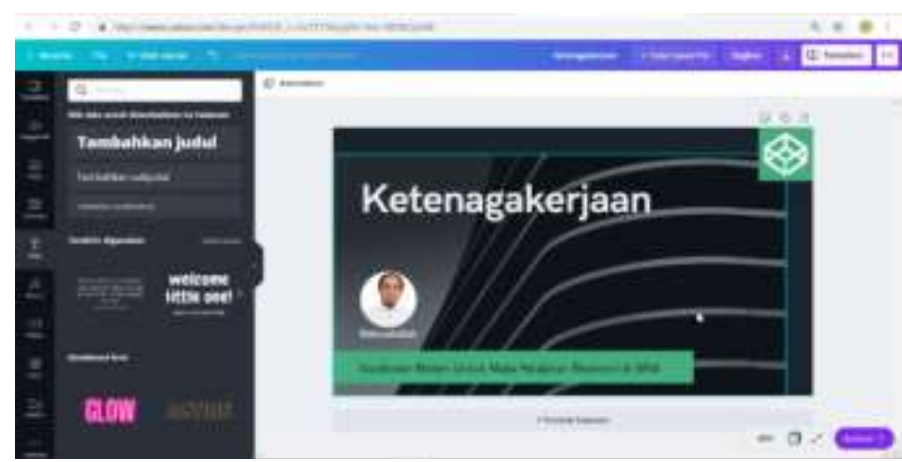

Gambar 6. Tampilan Menambahkan Teks Sumber: www.canva.com , 2020

Tergantung dengan teks ini, kita dapat melakukan pergantian baik itu ukuran, warna, model, maupun variasi dalam bentuk lainnya, sebagaimana ditampilkan pada kotak

warna merah pada gambar 7 berikut:

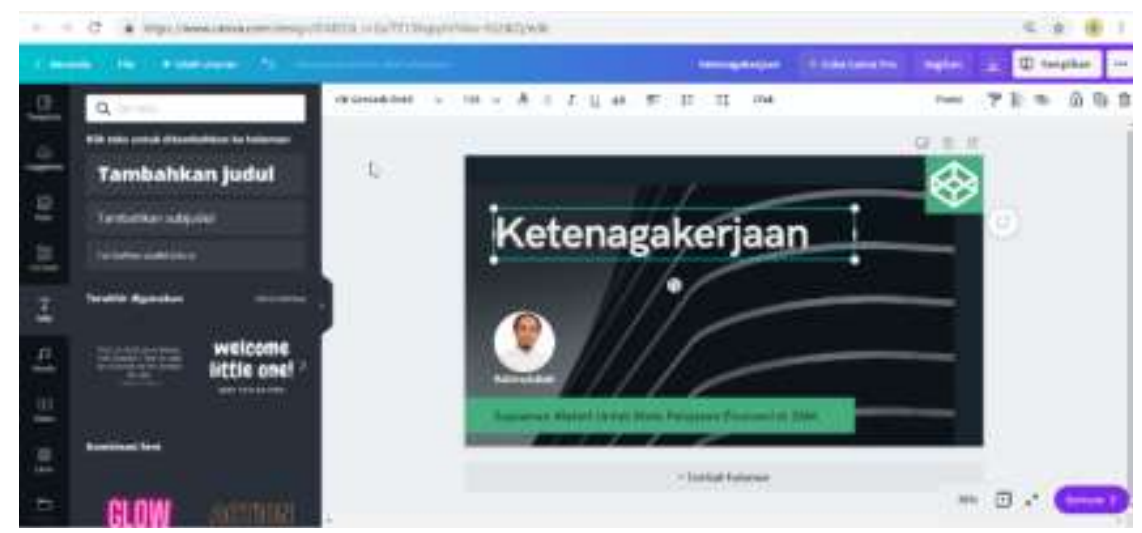

Gambar 10. Perubahan Tampilan Teks

Sumber: www.canva.com, 2020 
Keempat, melaksanakan penambahan konten audio visual. Dalam menambahkan audio visual, peneliti bisa mengeluarkan wajah sambil memberikan penjelasan terhadap konten materi pada media pembelajaran yang didesain. Ini dapat dilakukan dengan cara sebagaimana ditampilkan pada gambar 8 berikut.
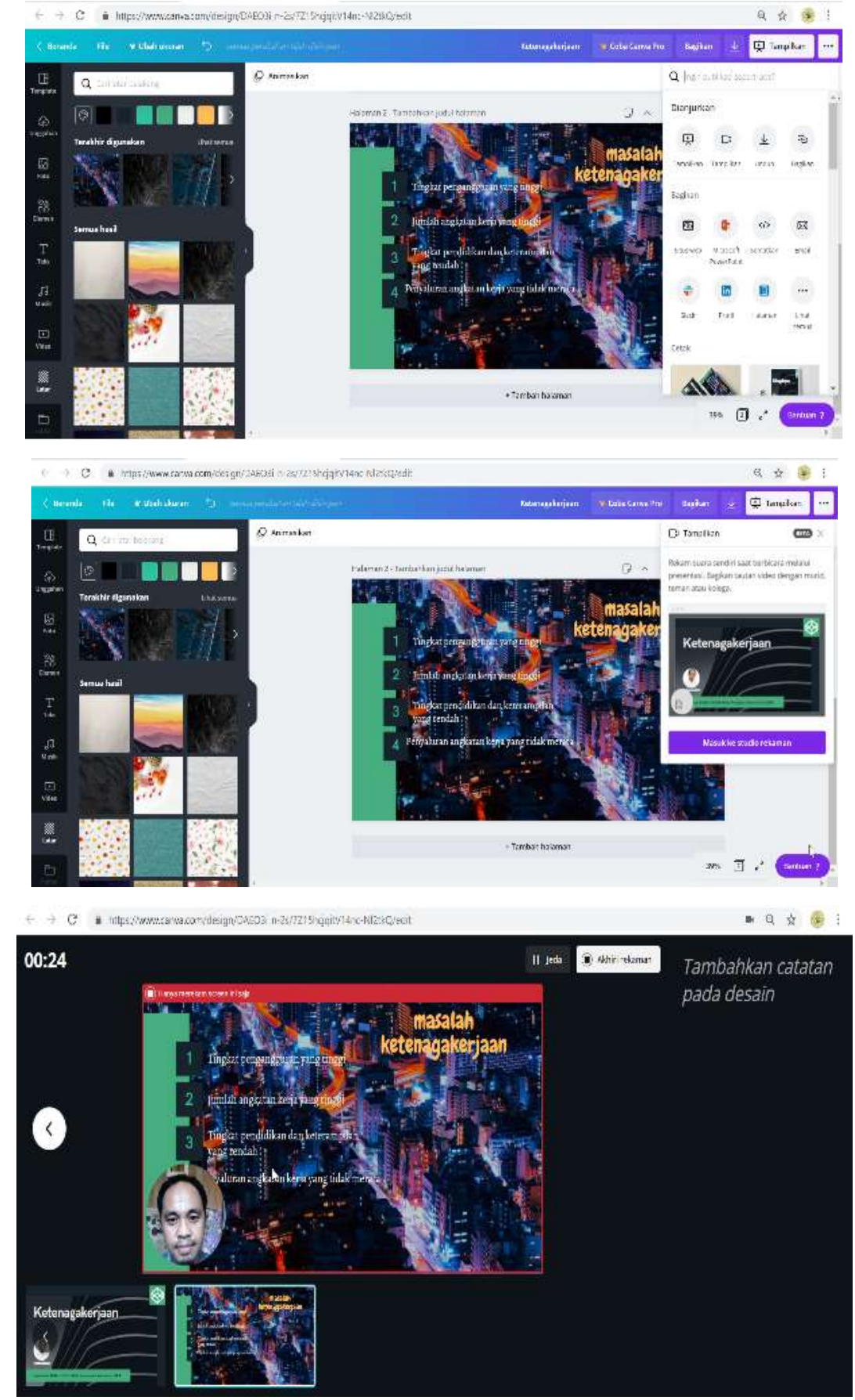


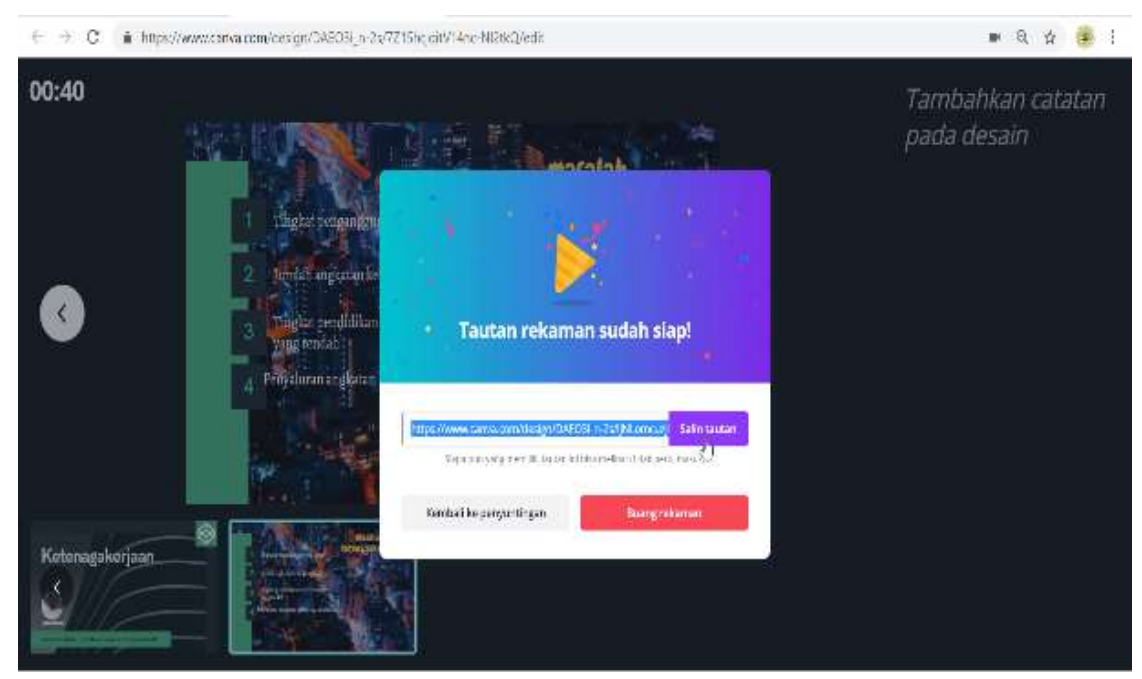

Gambar 10. Menambahkan Audio Visual

Sumber: www.canva.com, 2020

Bagian yang sudah ditandai pada gambar tersebut itu tujuannya agar dapat merancang teknik desain audio visual, dengan memilih tampilan pada bagian yang ditandai. Pada bagian ini kita ditunjukkan untuk masuk kepada bagian studi rekaman sebagai tempat untuk melaksanakan perekaman audio visual. Proses perekaman sedang berjalan maka posisi wajah yang akan ditampilkan dalam slide presentase sambil menjelaskan materi. Dibagian ini sudah ditampilkan tombol jeda dan akhiri rekaman. Kemudian proses perekaman berakhir maka dari itu akan muncul link link sebagai alamat hasil dari yang kita buat yang telah dilaksanakan. Link yang sudah ditampilkan silahkan disalin kemudian dibagikan ke peserta didik dengan menyebarkannya ke group kelas yang sudah ada untuk ditonton atau dilihat oleh peserta didik secara tidak tatap muka, sekaligus sebagai tanda bahwa proses desain audio visual telah selesai. Kelima, setelah proses desain ini telah diselesaikan, maka hasilnyaakan dapat atau didownload dan filenya disimpan secara offline. Setelah itu, file dari hasil desain dapat tersimpan secara otomatis. Untuk mendownload atau mengunduh file tersebut, silahkan pilih menu Download pada Tahap Uji Coba Lapangan

percobaan pada lapangan untuk dapat menilai keefektifan pengguna hasil dari desain media pembelajaran Audio visual yang berbasis aplikasi canva di laksanakan pada siswa kelas VI SD 02 Tarantang. Kegiatan percobaan ini dilaksanakan pretest dan posttest sehingga efektifnya proses dari pembelajaran dan hasil desain dapat kita ketahui. Hasil dari percobaan kita dapat kita simpulkan bahwa menggunakan media pembelajaran Audio visual berbasis aplikasi canva ini dimasukkan dalam kata berhasil. Maka dari itu dapat kita lihat pada table 4 berikut. Tabel 4. Hasil Uji Coba Pada Siklus 1 dan Siklus 2

\begin{tabular}{lllll}
\hline Jumlah siswa & Nilai rata-rata & Siklus 1 & Siklus & Ket \\
\hline
\end{tabular}




\begin{tabular}{lllll}
\hline & $\mathrm{A}$ & $\mathrm{B}$ & 2 & \\
& $(\%)$ & $(\%)$ & $(\%)$ & \\
36 orang & 59.16 & 75.10 & 88 & - \\
\hline Jumlah & 67.13 & & 88 & Sangat Baik \\
\hline
\end{tabular}

Sumber: Hasil Olah Data, 2020

Dilihat dari tabel 4 yang kita lihat yang mana informasi dari rata-rata hasil belajar siklus I sebesar 67.13 persen dan untuk siklus 2 sebesar 88 persen. Maka dari itu, adanya terjadi sebuah kenaikan dari hasil belajar siswa hingga secara luas siswa yang menjadi sampel uji percobaan lebih gampang untuk menguasai materi tenaga kerja memakai media pembelajaran Audio visual berbasis aplikasi canva dengan tolak ukur yang bagus.

\section{HASIL DAN PEMBAHASAN}

Keberhasilan dari proses pembelajaran itu adalah bagaimana dengan media yang kita gunakan harus di desain dengan semenarik mungkin hingga pandangan atau ketertarikan siswa itu bisa lebih berpusat kepada objek yang akan diajarkan, itu lah salah satu faktor keberhasilan dari proses pembelajaran. Adanya perkembangan kurikulum ini perlu adanya tunjangan dari guru sendiri yaitu dengan guru memiliki kemampuan dalam mengembangkan sebuah media pembelajarannya dan dapat meningkatkatkan suatu kualitas dalam mencapai pembelajaran yang diharapkan (Rusdiana et al., 2021). Aplikasi canva adalah aplikasi yang sangat tepat digunakan dalam mendesain media pembelajaran, karena di canava ini banyak terdapat template yang bisa dipergunakan untuk mendesain sebuah bentuk inti dari materi yang dapat membuat peserta didik senang dan memiliki ketertarikan untuk melihatnya, yang mana telah dikembangkan dalam pengkajian ini. Siswa pasti akan dapat lebih mudah memahami apanila media pembelajaran yang dibuat itu dengan luar biasa, atraktif, memukau ( Sutarno \& Mukhidin, 2013). Apabila kita kaitkan dengan teori kerucut kehidupan, bahwa lima puluh persen pengetahuan atau pengealaman belajar di dapatkan dari perasa manusia meringankan pemcapaian keterampilan dan penafsiran siswa.

Hasil dari pengkajian saat ini telah mengungkapkan bahwa pemakaian media pemebelajaran berbasis audio visual ini memang kronis penting dalam mengangkat pelaksanaan proses pembelajaran tatap muka maupun secara tidak tatap muka. Lain dari itu, hasil percobaan yang sudah diujikan juga disebutkan bahwa media yang dikembangkan ini sangat layak dilaksanakan dalam proses pembelajaran. Dapat dilihat ukuran dari kelayakan dari beberapa bentuk yang mana itu misalnya desain yang menarik, serta kejelasan konten materi yang telah disajikan dalam media tersebut. Faktor yang dapat mempengaruhi terhadap keberhasilan yaitu dari desain materi pembelajaran itu sendiri yaitu guru harus bisa membuat 
media yang sesuai agar siswa ini dapat merasa nyaman dan agar dapat mudah memahami materi yang akan mereka bahas (Rokhayani \& Utari, 2014).

\section{SIMPULAN}

Berdasarakan hasil penelitian maka dapat disimpulkan bahawa penggunakaan aplikasi canva untuk pembelajaran ilmu pengetahuan sosial sangat efektif di gunakan pada masa pandemi covid 19, sehingga mempermudah dalam pembelajaran tidak tatap muka baik bagi siswa maupun guru. Penggunaan aplikasi canva dalam pembelajaran ilmu pengetahuan sosial berbasis audio visual dengan aplikasi canva, bagian lain dapat juga menempatkan corak yang baru didalam berlansung nya prosedur pembelajaran pada mata pelajaran ilmu pengetahuan sosial, yang produktif dan inventif. Dakam pengkajian ini adabeberapa hal yang dapat di sarankan yakni, diperlukannya kesadaran dari semua belah pihak dalam menyokong dan mengimplementasikan pemebelajaran berbasis online atau tidak tatap muka ini, dengan aplikasi yang terrsedia. Meskipun aplikasi canva di sediakan secara gratis, tetapi jika tidak disokong oleh kesiapan sumber daya guru didalam menggunakannya maka proses pembelajaran online ini tidak lebih menyenangkan dari proses tatap muka, maka untuk itu baik kepala sekolah dan guru maupun siswa harus dimaksimalkan, optimalkan dan diintensifkan.

\section{DAFTAR PUSTAKA}

Abdul Syukur, I. (2014). Profesionalisme Guru dalam Mengimplementasikan Teknologi Informasi dan Komunikasi di Kabupaten Nganjuk. Jurnal Pendidikan Dan Kebudayaan, 20(2), 200. https://doi.org/10.24832/jpnk.v20i2.138

Bahri, S. (2015). Implementasi Pendidikan Karakter dalam Mengatasi Krisis Moral di Sekolah. Ta'allum: Jurnal Pendidikan Islam, 3(1), 57-76. https://doi.org/10.21274/taalum.2015.3.1.57-76

Bakri, N. F., Simaremare, E. S., Lingga, I. S., Susilowaty, R. A., Farmasi, J., Matematika, F., Alam, P., \& Cenderawasih, U. (2021). Jurnal Ilmiah Pro Guru, Vol .7 No . 1 , Januari 2021 ISSN : 2442 - 2525 , E_ ISSN : 2721-7906 PELATIHAN PEMBUATAN MATERI PRESENTASI DAN VIDEO PEMBELAJARAN MENGGUNAKAN APLIKASI CANVA KEPADA GURU DI KOTA MEDAN DAN JAYAPURA SECARA ONLINE Jurnal Ilmiah Pro. 7(1), 1-10.

Farmawati, E., Ramli, A., \& Rahmatullah, R. (2018). Faktor- Faktor Yang Mempengaruhi Kinerja Guru Ekonomi Pada Sma Negeri Di Kota Makassar. JEKPEND: Jurnal Ekonomi Dan Pendidikan, 1(2), 23. https://doi.org/10.26858/jekpend.v1i2.7267

Fitria, V. A., Habibi, A. R., Hakim, L., \& Islamiyah, M. (2021). Using Canva to Support Online Learning Media for Students at Mahardika Karangploso Vocational School in Malang during the Pandemic Pemanfaatan Canva untuk Mendukung Media Pembelajaran Online Siswa Siswi SMK Mahardika Karangploso Malang di Masa Pandemi. 1(2), 75-82.

Garris Pelangi. (2020). Pemanfaatan Aplikasi Canva Sebagai Media Pembelajaran Bahasa Dan 
Sastra Indonesia. Jurnal Sasindo Unpam, Vol 8, No 2, Desember 2020 PEMANFAATAN, 8(2), 79-96.

Hapsari, G. P. P., \& Zulherman. (2021). Pengembangan Media Video Animasi Berbasis Aplikasi Canva untuk Meningkatkan Motivasi dan Prestasi Belajar Siswa. Jurnal Basicedu, 5(4), 2384-2394.

Imron, M. (2021). Penerapan Model Pembelajaran Kooperatif Tipe Snowball Throwing Untuk Meningkatkan Hasil Belajar Siswa Min Kudus. JIRA: Jurnal Inovasi Dan Riset Akademik, 2(2), 152-163. https://doi.org/10.47387/jira.v2i2.81

Işman, A. (2011). Instructional design in education: New model. Turkish Online Journal of Educational Technology, 10(1), 136-142.

Mahardika, A. I., Wiranda, N., \& Pramita, M. (2021). Pembuatan Media Pembelajaran Menarik Menggunakan Canva Untuk Optimalisasi Pembelajaran Daring. Jurnal Pendidikan Dan Pengabdian Masyarakat, 4(3), 275-281.

Mahnun, N. (2012). Media Pembelajaran (Kajian terhadap Langkah-langkah Pemilihan Media dan Implementasinya dalam Pembelajaran). An-Nida', 37(1), 27-35.

Nasrullah, M., Ilmawati, I., Saleh, S., Niswaty, R., \& Salam, R. (2018). Minat Menjadi Guru Pada Mahasiswa Program Studi Pendidikan Administrasi Perkantoran Fakultas Ilmu Sosial Universitas Negeri Makassar. Jurnal Ad'ministrare, 5(1), 1-6.

Nurhisam, L. (2017). Sebagai Solusi Dekadensi Moral Anak.

Nurseto, T. (2012). Membuat Media Pembelajaran yang Menarik. Jurnal Ekonomi Dan Pendidikan, 8(1), 19-35. https://doi.org/10.21831/jep.v8i1.706

Pebriana, P. H. (2017). Analisis Penggunaan Gadget terhadap Kemampuan Interaksi Sosial pada Anak Usia Dini. Jurnal Obsesi: Jurnal Pendidikan Anak Usia Dini, 1(1), 1. https://doi.org/10.31004/obsesi.v1i1.26

Pratiwi, D., Santoso, G. B., Mardianto, I., Sediyono, A., \& Rochman, A. (2020). Pengelolaan Konten Web Menggunakan Wordpress , Canva dan Photoshop untuk Guru-Guru Wilayah Jakarta Web Content Management Using Wordpress , Canva and Photoshop for Teachers of the Jakarta Region. Jurnal Ilmiah Pengabdian Pada Masyarakat, 2(1), 12.

Purwati, Y., \& Perdanawanti, L. (2019). Pelatihan Desain Menggunakan Aplikasi Canva. Jurnal Pengabdian Mitra Masyarakat (JPMM) Vol., 1(1), 42-51.

Rahmasari, E. A., \& Yogananti, A. F. (2021). Kajian Usability Aplikasi Canva (Studi Kasus Pengguna Mahasiswa Desain). ANDHARUPA: Jurnal Desain Komunikasi Visual \& Multimedia, 7(01), 165-178. https://doi.org/10.33633/andharupa.v7i01.4292

Rahmatullah, R., Inanna, I., \& Ampa, A. T. (2020). Media Pembelajaran Audio Visual Berbasis Aplikasi Canva. Jurnal Pendidikan Ekonomi Undiksha, 12(2), 317-327.

Resmini', S., Satriani, I., \& Rafi, M. (2021). Pelatihan Penggunaan Aplikasi Canva sebagai Media Pembuatan Bahan Ajar dalam Pembelajaran Bahasa Inggris. Abdimas Sliwangi, 04(02), 335-343.

Rokhayani, A., \& Utari, A. R. P. (2014). the Use of Comic Strips As an English Teaching Media. LANGUAGE CIRCLE Journal of Language and Literature, VIII(April), 143-149.

Rusdiana, R. Y., Putri, W. K., \& Sari, V. K. (2021). Pelatihan Pembuatan Media Pembelajaran Menggunakan Canva bagi Guru SMPN 1 Tegalampel Bondowoso.

Santi, I. N., \& Mubaraq, R. (2020). Pelatihan Membuat Logo Usaha Training Makes a Business Logo. 8(November), 41-45.

Sholeh, M., Rachmawati, R. Y., \& Susanti, E. (2020). Penggunaan Aplikasi Canva Untuk Membuat Konten Gambar Pada Media Sosial Sebagai Upaya Mempromosikan Hasil Produk Ukm. SELAPARANG Jurnal Pengabdian Masyarakat Berkemajuan, 4(1), 430. https://doi.org/10.31764/jpmb.v4i1.2983

Suni Astini, N. K. (2020). Tantangan Dan Peluang Pemanfaatan Teknologi Informasi Dalam Pembelajaran Online Masa Covid-19. Cetta: Jurnal Ilmu Pendidikan, 3(2), 241-255. 
https://doi.org/10.37329/cetta.v3i2.452

Tahun, B. J., Kalor, P., Sd, D. I., Melinda, T., \& Saputra, E. R. (2021). Jurnal Inovasi Pendidikan Dasar CANVA SEBAGAI MEDIA PEMBELAJARAN IPA MATERI. 5(2), 96101.

Tiawan, Musawarman, Sakinah, L., Rahmawati, N., \& Salman, H. (2020). Pelatihan Desain Grafis Menggunakan Aplikasi Canva Tingkat Smk Di Smkn 1 Gunung Putri Bogor. BERNAS: Jurnal Pengabdian Kepada Masyarakat, 1(4), 476-480. https://doi.org/10.31949/jb.v1i4.417

Triningsih, diah erna. (2021). Penerapan Aplikasi Canva untuk Meningkatkan Kemampuan Menyajikan Teks Tanggapan Kritis Melalui Pembelajaran Berbasis Proyek. Paper Knowledge . Toward a Media History of Documents, 15(1), 128-144. https://doi.org/10.30957/cendekia.v15i1.667.Selama

Wicaksana, E. J., Atmadja, P., \& Asmira, Y. (2020). Pengembangan Poster Kesehatan Reproduksi Berbasis Pendidikan Karakter Menggunakan Canva pada Usia Remaja Sekolah di SMA. Jurnal Penelitian Dan Pengkajian Ilmu Pendidikan: E-Saintika, 4(2), 160. https://doi.org/10.36312/e-saintika.v4i2.215

Yuanta, F. (2020). Pengembangan Media Video Pembelajaran Ilmu Pengetahuan Sosial pada Siswa Sekolah Dasar. Trapsila: Jurnal Pendidikan Dasar, 1(02), 91. https://doi.org/10.30742/tpd.v1i02.816 